\title{
Kompetencje menedżerskie na tle wyzwań konkurencji globalnej - profil polskiego menedżera
}

https://doi.org/10.33141/po.2005.06.05

Elżbieta Jadwiga Biesaga-Słomczewska
Przegląd Organizacji, Nr 6 (785), 2005, ss. 22-25 www.przegladorganizacji.pl Towarzystwo Naukowe Organizacji i Kierownictwa (TNOiK)

\section{Konieczność myślenia globalnego}

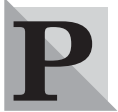

olskie firmy pragnąc stać się przedsiębiorstwami globalnymi muszą stanąc przed ogromnym wyzwaniem, jakim jest odpowiedni rozwój kompetencji, przez które rozumie się w tym przypadku unikatowe zdolności (umiejętności) umożliwiające wykorzystanie zasobów, tj. kadr, ich kwalifikacji i wiedzy, bazy danych i informacji lepiej niż czyni to konkurencja ${ }^{1)}$.

Umiejętność działania na skalę międzynarodową wiąże się z koniecznością przewidywania wpływu decyzji i działań ekonomicznych w skali globalnej na działania konkretnej firmy. Dotychczas do odniesienia sukcesu wystarczała menedżerowi wiedza z zakresu ekonomii, dziś równie ważna jest wiedza ogólna o świecie. Trafnie określił to D. Urlich stwierdzając, że menedżer powinien „działać lokalnie, a myśleć globalnie" ${ }^{2)}$. Dawne poczucie bezpieczeństwa płynące z przynależności jednostki do większej grupy musi zastąpić świadomość potrzeby rozwijania wspólnego sposobu myślenia, czy wypracowania swobodnej wymiany pomysłów w płaszczyźnie globalnej, a nie lokalnej.

\section{Rosnąca świadomość praw klienta}

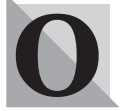

twarcie gospodarki polskiej na świat spowodowało zmianę nastawienia klienta do oferty rynkowej. Współczesny klient stał się bardziej świadomy swoich praw i tym samym krytyczny wobec funkcjonowania różnych instytucji i procedur obsługi. Chcąc zdobyć klienta, trzeba dostarczyć mu niepowtarzalnych wartości ${ }^{3}$. Przez wartość rozumie się w tym przypadku nie tylko wysokie parametry techniczno-technologiczne produktu, nie tylko dogodną dystrybucję (na czas, na miejsce) czy konkurencyjną cenę, ale gotowość do utrzymywania kontaktów, szybką reakcję, a także wysoki poziom kultury obsługi połączony z kompetencjami pracowników. Aby pozostać konkurencyjnym, należy więc stworzyć takie procedury działania, które będą bardziej wrażliwe na potrzeby klienta. Ta wrażliwość powinna przejawiać się chociażby w gotowości do wprowadzania innowacji czy w szybszym podejmowaniu decyzji. Wymaga to jednak nowego spojrzenia menedżera na zarządzanie zasobami ludzkimi w firmie i potraktowania dostawców, pracowników i klientów jako swoistego rodzaju zespołu, który współuczestniczy w tworze- niu tej wartości. Zatem kompetentni menedżerowie muszą wykazać się poza innymi również umiejętnością „scalania” różnych części przedsiębiorstwa, w celu stworzenia wartości oczekiwanej przez klienta. By wytworzyć w firmie właściwe nastawienie do procesu tworzenia „wartości” dla klienta trzeba zagwarantować określony klimat współpracy. Osiągnie się to wówczas, jeśli spojrzy się na pracowników firmy jak na jej klientów wewnętrznych i będzie się postępować zgodnie z założeniami marketingu personalnego ${ }^{4}$. Umocowana w marketingu personalnym teoria lojalności pracowniczej zakłada, że stopień identyfikacji z firmą wpływa na pozytywne nastawienie do klienta zewnętrznego, który przenosi własny odbiór usługodawcy czy reprezentanta firmy na całościowy wizerunek ${ }^{5}$. Potwierdzają to wyniki badań, w świetle których pozytywne nastawienie pracowników do firmy generuje właściwe relacje z klientami zewnętrznymi. Na jakość tych relacji ma wpływ zarówno system komunikacji wewnętrznej, odpowiednio ukształtowane stosunki podległościowe czy system motywacyjny obowiązujący w firmie ${ }^{6)}$.

\section{Konieczność podnoszenia rentowności przez rozwój}

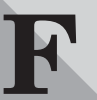

irmy, chcąc sprostać konkurencji, muszą dążyć do rentowności nie tylko przez minimalizowanie kosztów, ale przez rozwój. Rentowność nadal pozostanie najważniejszym atutem firmy, ale musi ulec zmianie droga do jej osiagania. W coraz większym stopniu musi być to wynik jednoczesnego zwiększania zysku i ograniczania kosztów. G. Hamel i C.K. Prahalad ${ }^{7)}$ są zwolennikami koncepcji zwiększania rentowności przez rozwój, który ich zdaniem można osiągnąć m.in. poprzez wywieranie wpływu na klientów i skłanianie ich, przy zastosowaniu różnych instrumentów marketingowych, do zakupu większej ilości produktów, czy przez pełne wykorzystanie kluczowych i tworzenie nowych produktów, które oznaczają dla firmy generowanie dochodów.

Przedstawiona koncepcja zwiększania rentowności przez rozwój, niezależnie od sposobu jej osiagania, stawia nowe wyzwania przed menedżerami w zakresie metod zarządzania zasobami ludzkimi i tworzenia warunków do samorozwoju, do realizacji indywidualnych potrzeb pracowników, do odpowiedzialności za dokonywane wybory i zachowania. Jest to szczegól- 
nie ważne w sytuacji, gdy wzrasta liczba ludzi czasowo zatrudnionych bez pewności stałego zatrudnienia, gdy wręcz standardem staje się employability ${ }^{8}$, czyli stan zdolności do bycia zatrudnionym. Na tym tle może pojawić się wiele problemów chociażby związanych z wytwarzaniem poczucia lojalności i zaangażowania względem organizacji, która nie gwarantuje stabilizacji. Właściwa postawa menedżera, jego etyczne zachowania, profesjonalizm, umiejętność koordynowania i integrowania wysiłków grupy wokół wspólnych celów może zapobiec wielu negatywnym zachowaniom. Może spowodować, że formalny autorytet wynikający z władzy staje się autorytetem rzeczywiście akceptowanym przez pracowników, wyzwalajacym ich kreatywność i zaangażowanie. Firmie potrzebny jest zatem menedżer, który przewodzi, inspiruje pracowników, dostarczając im wizji i motywacji do ich rozwoju. Pod wpływem menedżera-przywódcy pracownicy zachowują się w sposób pożądany, zgodny z realizowaną strategią, rozwijając przy tym swoją osobowość i poczucie własnej wartości ${ }^{9}$. Umiejętności pojedynczych pracowników przekształcają się tym samym w potencjał organizacji, na który składają się zarówno profesjonalizm ludzi tam pracujacych, technologie, kondycja finansowa, jak i umiejętności organizacyjne (np. zdolność do szybkiego działania).

\section{Konieczność zaakceptowania nieuchronności zmiany}

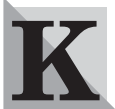

onieczność zaakceptowania przez kadrę zarządzającą firmą nieuchronności zmiany nie zawsze jest właściwie postrzegana, wręcz często bagatelizowana i niezauważana. Wynika to $\mathrm{z}$ istoty zmiany, która jest kategorią niejednorodną, mająca różną treść i zasięg, ale też zakładającą możliwość świadomej i celowej interwencji człowieka w jej źródło i procesy przebiegu. Świadomość stałości zmiany wymaga od menedżera nowych sposobów postrzegania procesów zachodzących w firmie, nowego sposobu myślenia i zachowania. Menedżer i pracujaccy z nim ludzie muszą być otwarci na zmiany, ale decydujac się na nie powinni zawsze uwzględnić potrzeby i możliwości organizacji oraz cel, który ta organizacja chce spełnić. Może bowiem pojawić się wiele trudności, które opóźnią lub całkowicie uniemożliwią realizację procesu zmian.

Zmiany muszą następować etapami. Przyspieszanie tego procesu bez zapewnienia odpowiedniego gruntu może spowodować wiele strat. J.P. Kotter ${ }^{10)}$ przestrzega przed popełnieniem podczas procesu zmian następujaccych błędów, które jego zdaniem zdarzają się nawet najzdolniejszym menedżerom.

Błąd 1. Niedostateczne uświadomienie pracownikom konieczności dokonania zmian. By zaistniała współpraca ze strony wielu ludzi pracujących w firmie, musi być akceptacja konieczności zmian (co najmniej $75 \%$ ludzi w firmie musi akceptować zmiany).

Błą 2. Brak silnej koalicji liderów. Na ogół w skład zespołu popierającego zmiany nigdy nie wchodzą wszyscy członkowie kierownictwa firmy. Należy zatem dążyć, by stworzyć jak najsilniejszą koalicję pod względem stanowisk.

Btad 3. Brak wizji zmiany. Koalicja liderów musi umieć przedstawić wizję, która zostanie zaakceptowa- na przez klientów, udziałowców i pracowników firmy, w różnych jej płaszczyznach, tj. księgowości, oceny efektywności pracowników, podnoszenia jakości czy zmiany kultury sprzedaży.

Bład 4. Niewłaściwe komunikowanie o istocie wizji. Często pracownicy traktują wizję jako nierealną, gdyż zachowanie menedżerów wysokiego szczebla jest zaprzeczeniem tego, co faktycznie dzieje się w firmie. Konsekwencją braku spójności deklaracji z rzeczywistym działaniem jest zwątpienie pracowników i ograniczenie zaufania do przekazywanych informacji.

Błąd 5. Nieusunięcie przeszkód utrudniających realizowanie wizji, wynikających na ogół z mentalności, braku zrozumienia istoty zmiany (np. zachowanie starych zasad w zakresie polityki kadrowej, które wyraźnie nie przystają do nowych koncepcji).

Bład 6. Brak systematycznego działania. Prawdziwe zmiany wymagaja czasu i sa procesem długotrwałym. Należy więc wziąć pod uwagę fakt, że większość ludzi nie zdobędzie się na długotrwały wysiłek, jeśli w krótkim czasie nie pojawią się przekonujace dowody na to, że ich starania przynoszą spodziewane rezultaty. Bez widocznych rezultatów w krótkim okresie ludzie rezygnują z dalszych starań lub przechodzą na stronę tych, którzy aktywnie sprzeciwiają się zmianom ${ }^{11)}$.

Btad 7. Świętowanie zwycięstwa zanim nastąpi ugruntowanie zmiany. Często po widocznej poprawie wyników firmy następuje przedwczesna radość i zaniechanie wprowadzania dalszych etapów przekształceń, w skutek czego wszelkie dokonane dotychczas pożyteczne zmiany powoli ustępują miejsca dawnym rozwiazaniom. Zmiany można uznać za trwałe, jeśli pracownicy zaczynają o nich mówić jak o własnym stylu pracy, jeśli staną się organicznym elementem społecznych norm i wspólnych wartości nawet wówczas, gdy osłabnie presja w kierunku ich wprowadzania. P. Kotter ${ }^{12)}$ wyróżnia dwa czynniki, które mają największy wpływ na ich utrwalenie w ramach kultury organizacyjnej firmy. Pierwszym z nich jest rozmyślne dążenie do uświadomienia pracownikom, w jaki sposób ich nowe podejście sprzyja poprawie wyników. Drugim zaś czynnikiem jest powolne i konsekwentne skłanianie ekipy menedżerskiej, by utożsamiała się z modernizacją.

\section{Imperatyw przyspieszonego rozwoju organizacji opartej na wiedzy}

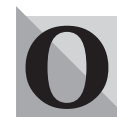

bserwatorzy życia gospodarczego podkreślają, że przy wycenie firmy bierze się coraz częściej pod uwagę, poza tradycyjnie występującymi elementami wpływającymi na kapitał, potencjał wiedzy, którym ona dysponuje. Uważa się, że zasoby wiedzy i zdolności intelektualne decydują o szybkości procesów dostosowawczych wewnątrz organizacji w odpowiedzi na zmiany otoczenia. Zdolności innowacyjne organizacji są zależne od efektywności tworzenia wiedzy. Ludzie wspierani właściwą informacją pozyskują wiedzę i mądrość, a tym samym przyczyniaja się do wzrostu konkurencyjności firmy ${ }^{13}$.

Czynienie wiedzy produktywną wymaga od menedżera dużego wysiłku intelektualnego i organizacyjnego ${ }^{14)}$. Dochodzi bowiem często do złego gospodarowania wiedzą. Błędy wynikają głównie z ulegania ste- 
reotypom myślowym i z braku zrozumienia istoty organizacji opartej na wiedzy, nazwanej przez P. Senge'a „organizacją uczącą się"15). Firmy zbyt często konkurują na płaszczyźnie cenowej, co nie idzie w parze z procesem pozyskiwania wiedzy. Poza tym brak jest wypracowanych standardów w zakresie przekazywania dobrych pomysłów pracownikom i dzielenia się nimi. Koncepcja organizacji opartej na wiedzy (organizacji „uczącej się”) zakłada bowiem zespalanie w jedną całość wszystkich przedsięwzięć realizowanych w organizacji. W szczególności działania organizacji zmierzają w kierunku generowania nowej wiedzy, pozyskiwania wiedzy z otoczenia (od partnerów, klientów, konkurentów) i przetwarzania wiedzy indywidualnej w zbiorową (organizacyjną). Oznacza to konieczność transferu wiedzy między poszczególnymi komórkami po to, by móc ją wykorzystać do podejmowania trafnych decyzji ${ }^{16}$. By to osiągnać, trzeba uczynić wiedzę zrozumiałą dla każdego. Uwaga menedżera powinna być skoncentrowana na uczeniu pracowników i rozwijaniu ich kompetencji. Uznanie wiedzy jako jednego z cennych zasobów organizacji rodzi jednak określone problemy dla menedżera. Zdając sobie sprawę z faktu, że im większą wiedzę posiada, tym większy ma prestiż w środowisku, niechętnie rezygnuje z wyłączności na jakikolwiek z jej obszarów ${ }^{17)}$. Jeżeli już decyduje się udostępnić wiedzę innym osobom, musi mieć do nich zaufanie. Należy pamiętać o tym, że pracownik obawiajaccy się utraty pracy nie będzie miał ochoty dzielić się swoim doświadczeniem i swoją wiedzą, będzie stwarzał natomiast wrażenie, że jest niezastapiony (jest to szczególnie istotne w przypadku stosowania ruchomych form zatrudniania pracowników np. na zasadach outsourcingowych).

I. Nonaka i H. Takeuchi wymieniaja wiele czynników, które być może zminimalizują pojawiające się problemy w zakresie tworzenia wiedzy na szczeblu organizacji. Zdaniem autorów, łatwiej będzie wprowadzać w życie nową ideę, jeśli będzie ona powiązana ze strategią organizacji (np. nie może w tym przypadku być mowy o konkurowaniu poprzez ceny), jeśli zapewniona zostanie autonomia jednostek i zespołów w tworzeniu wiedzy (pomysły pozostają w zespołach), jeśli organizacja będzie otwarta na sygnały płynące z rynku i będzie gotowa do zmian, jeśli zapewniony będzie równy dostęp ogółu pracowników do informacji ${ }^{18)}$. S. Borkowska $^{19)} \mathrm{z}$ kolei uważa, że do kreowania wiedzy na szczeblu organizacji konieczne jest stworzenie odpowiedniego gruntu w zakresie podniesienia kwalifikacji polskiego społeczeństwa i takiej budowy systemu edukacji, który będzie sprzyjał doskonaleniu umiejętności zwiększania kompetencji. Wymaga to również zmiany struktury zatrudnienia na rzecz pracowników o wysokich kwalifikacjach oraz budowania kultury organizacyjnej sprzyjającej rozwojowi pracowników. Zatem poza kompetencjami specjalistycznymi menedżera, znaczenia nabierają kompetencje ogólne, takie jak zdolność do uczenia się przez całe życie, dzielenie się wiedzą, innowacyjność czy komunikacja. Kształtowanie tych kompetencji wiąże się z taką kulturą organizacyjną, która ułatwia wewnętrzną integrację pracowników oraz dostosowywanie się do zmian otoczenia. Cz. Sikorski ${ }^{20)}$ nazywa tę kulturę „kulturą nowej gospodarki”, która charakteryzuje się m.in. wysoką tolerancją niepewności w środowisku społecznym organizacji, akceptowaniem różnorodności działań zamiast standaryzacji, wzrostem emancypacji pracowniczej, szerszą autonomią pracowników wiedzy, heterogenizacją kultury organizacyjnej w efekcie wzrastającej złożoności relacji organizacji z otoczeniem.

Wypracowanie wiedzy, czyli kapitału intelektualnego w firmie jest możliwe, ale wówczas, gdy proces ten opierać się będzie nie na indywidualnej rywalizacji, lecz na rezygnacji z autorstwa pomysłów czy projektów na rzecz osiagnięć zespołów. „Nader ważne jest kształtowanie wartości etycznych, klimatu zaufania, dopuszczenie prawa do błędu i twórczej destrukcji, aby nie blokować pomysłowości i zaangażowania pracowników"21). Uczenie się w organizacji i podnoszenie wartości kapitału intelektualnego przebiegać będzie szybko tylko wówczas, gdy menedżerowie przełożą „...możliwości na wizję, wizję na działanie, a wreszcie dostosują działanie do potrzeb klientów"22). By jednak było to możliwe, trzeba stworzyć wspierającą politykę i działalność z zakresu motywowania, odpowiedni system obiegu informacji czy też dochodzenia do porozumienia między komórkami organizacyjnymi nie na zasadzie rywalizacji, ale wzajemnej kooperacji i uzgadniania stanowisk chociażby w drodze negocjacji. Znajduje to również odbicie w systemie motywowania ${ }^{23)}$.

Kolejny problem zarysowujący się na tle rozwoju organizacji opartej na wiedzy to podejście do władzy. Zdaniem B.R. Kuca współczesne organizacje „potrzebują menedżerów, ale czekają na przywódców, którzy uskrzydlą ich działania, napełnią ludzi energią i entuzjazmem, zagwarantują stabilność i rozwój w burzliwym otoczeniu"24). Przywództwo sprzyja menedżerowi w przekonaniu innych, by entuzjastycznie dążyli do określonych celów. Przywództwo rozumiane w tym sensie jest wyrazem osobistej władzy menedżera (leadership). Władza ta wywodzi się jednak nie tylko z usankcjonowanych uprawnień, dających menedżerowi możliwość przymuszenia innych, lecz przede wszystkim opiera się na cechach osobowości, entuzjazmie, determinacji i gotowości do poświęceń.

W organizacji opartej na wiedzy ważne jest nie posłuszeństwo (nie można dzielić się wiedzą na zasadzie przymusu) i rutynowe wykonywanie zadań, lecz autentyczne, pełne zaangażowanie. Wymaga to stopniowego wycofania się $\mathrm{z}$ taylorowskiej koncepcji pracy, dzielącej ludzi na tych, którzy myślą i na tych, którzy wykonują polecenia i uznania, że każdy pracownik wnosi wkład w kreowanie wartości dla klienta, dysponujacc pewnym marginesem autonomii. Jest to możliwe w organizacji zorientowanej poziomo, słabiej wyznaczającej granice między poszczególnymi jednostkami organizacyjnymi, funkcjonujaccej na podstawie procesów i projektów, redukującej hierarchiczne struktury władzy. B.R. Kuc uważa jednak, że nawet najbardziej płaska struktura nie może być pozbawiona elementu hierarchii ${ }^{25)}$. Problem polega zatem na określaniu zakresu, w jakim tę hierarchię należy uwzględnić. Istotę zależności podległościowych w organizacji trafnie określił W.E. Fulmer, według którego można zarządzać rzeczami, ludziom trzeba przewodziće ${ }^{26)}$. Członkowie organizacji chętniej akceptuja stosunki podległościowe na zasadzie przewodzenia. Menedże- 
rowie powinni więc dążyć do wyzwalania u pracowników ich kreatywności oraz zainteresowania zdobywaniem i wykorzystywaniem aktywnej wiedzy (informacji) i powinni przestać zarządzać - w tradycyjnym rozumieniu - ludźmi, a skoncentrować się na przestrzeni, gdzie ta wiedza powstaje. Przestrzeń ta to nie tylko fizyczne biuro, ale przede wszystkim kultura organizacji, która będzie sprzyjać przekształcaniu wiedzy indywidualnej w wiedzę organizacji ${ }^{27)}$. Dobry menedżer-przywódca obserwuje więc reakcje ludzi, z którymi współpracuje, liczy się z ich opiniami, zauważa emocje, sprawiedliwie ocenia ich wysiłki, a dopiero potem podejmuje decyzje, za które bierze odpowiedzialność. Takie postępowanie pozwala budować zaufanie i nieformalny autorytet, które sa podstawa przywództwa i tworzenia relacji międzyludzkich. Przywództwo jest potrzebne, aby inspirować ludzi i zwiększać ich satysfakcję z pracy. Jest potrzebne, gdyż ludzie czując, że mają kontrolę nad swoją praca, starają się uczestniczyć w procesie samodoskonalenia się i osiagać lepsze wyniki. Twórcze myślenie nad usprawnianiem własnej pracy, podniesieniem jej wydajności i efektywności staje się obowiązkiem każdego pracownika, niezależnie od zajmowanego przez niego stanowiska $^{28)}$.

W praktyce autorytet przywódcy menedżera może spowodować niekontrolowane reakcje pracowników. Może się zdarzyć, że podwładni oczekują od przywódcy „magicznych rozwiązań.” Jeżeli ich nie uzyskaja, może dojść do kryzysu zaufania. Może dojść również do sytuacji, w której pracownicy będąc pod wpływem „autorytetu”, obawiają się wyrażać swoje zdanie, uważając je za mało istotne. „Wszechwiedzący” przywódca może więc doprowadzić do pasywnego oczekiwania wszystkich na jego decyzje.

\section{Czy polski menedżer jest przygotowany do sprostania pojawiającym się wyzwaniom?}

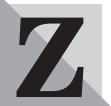

daniem B. Wawrzyniaka ${ }^{29)}$ polscy menedżerowie $\mathrm{w}$ większości nie rozumieją nowego otoczenia przedsiębiorstwa, co być może wynika z braku doświadczenia w gospodarce rynkowej. To powoduje, że nie mogą skutecznie odpowiadać na wyzwania globalizacji, które kształtują to otoczenie. W. Ratyński ${ }^{30)}$ podejmuje próbę enumeracji cech menedżera polskiego poprzez zwrócenie uwagi na zachowania, które w sposób szczególny określają jego profil. Jego zdaniem polscy menedżerowie wykazują: powolność w podejmowaniu decyzji, brak elastyczności i niechęć do brania za nie odpowiedzialności, brak niekonwencjonalnego podejścia do rozwiązywania problemów firmy, powielanie rozwiązań z przeszłości, czy niechęć do zachowań innowacyjnych.

dr Elżbieta Jadwiga Biesaga-Stomczewska PRZYPISY

Katedra Marketingu Uniwersytetu Łódzkiego

1) M. RYBAK (red.), Kapitat ludzki a konkurencyjność przedsiebiorstw, Poltext, Warszawa 2003, s. 16.

2) D. ULRICH, Liderzy zarzadzania zasobami ludzkimi. Nowe wyzwania, nowe role, Oficyna Ekonomiczna, Kraków 2001, s. 17.

3) D. URLICH, D.LAKE, Organizational Capabicity: Competing from the Inside/Out. Wiley, New York 1990, cyt. za: D. URLICH, Liderzy..., op.cit., s. 29.
4) Por: L. ZBIEGIEN-MACIAGG, Marketing personalny, Warszawa 1996; K. SCHWAN, K.G. SEIPEL, Marketing kadrowy, C.H.BECK, Warszawa 1996; E.J. BIESAGASŁOMCZEWSKA, Marketing personalny - zatożenia i praktyka polskich firm, [w:] Marketing - narzędzia i obszary zastosowań, „Acta Universitatis Lodziensis. Folia Oeconomica" 168, UŁ, Łódź 2003, s. 87-97.

5) Employer Brand Evolution: A Guide to Building Loyalty in Your Organization, Versant InterBrand Brand Papers 2001 (www.brandchannel.com).

6) B. SCHNEIDER, D.E. BOWEN, Winning the Service Game, Harvard Business School Press, Boston 1995; D. ULRICH, R. HALBROOK, D. MEDER, M. STUCHLIK, Employee and Customer Attachment: Synergies for Competitive Advantage, „Human Resource Planning” 1991, nr 2, s. 89-102.

7) G. HAMEL, C.K. PRAHALAD, Competing for the Future, Harvard Business School Press, Boston 1994.

8) J. BRILMAN, Nowoczesne koncepcje i metody zarzadzania, PWE, Warszawa 2002, s. 343.

9) K. NIZIŃSKA, Menedżer przywódca, „Manager” 2002, $\mathrm{nr} 6$.

10) J.P. KOTTER, Przewodzenie procesem zmian: przyczyny niepowodzeń, „Harvard Business Review” 2004, nr 17 (www.harvard.com)

11) Uzyskanie rezultatów $\mathrm{w}$ krótkim czasie jest często niemożliwe jak np. w przypadku podnoszenia kultury obsługi klienta, gdzie wymierne korzyści zauważa się dopiero w długim okresie, w krótkim zaś orientacja na klienta zwiększa jedynie koszty działalności.

12) J.P. KOTTER, Przewodzenie procesem..., op.cit.

13) I.P. RUTKOWSKI, Zasoby intelektualne firmy $i$ inteligentny system informacyjny strategii marketingowych, „Marketing i Rynek" 2003, nr 1 .

14) P.F. DRUCKER, Społeczeństwo pokapitalistyczne, PWN, Warszawa 1999, s. 14.

15) P. SENGE, Piata dyscyplina. Teoria i praktyka organizacji uczacych się, Dom Wydawniczy ABC, Warszawa 1998, s. 12 .

16) S. FORLICZ, Niedoskonata wiedza podmiotów rynkowych, PWN, Warszawa 2001, s. 32.

17) G. PROBST, S. RAUB, K. ROMHARDT, Zarzadzanie wiedza $w$ organizacji, Oficyna Ekonomiczna, Kraków 2002, s. 10.

18) I. NONAKA, H. TAKEUCHI, Kreowanie..., op.cit., s. 90.

19) S. BORKOWSKA, Gospodarka oparta na wiedzy. Wyzwania dla Polski o rozwój zasobów ludzkich, [w:] (red) A. LUDWICZYŃSKI, Najlepsze..., op.cit., s. 9.

${ }^{20)}$ Cz. SIKORSKI, Science, Technology and Industry Scoreboard 2001, Towards a Knowledge, Based Economy 2001, s. $35-38$.

21) S. BORKOWSKA, Gospodarka..., op.cit., s. 22.

22) D. ULRICH, Liderzy..., op.cit., s. 27.

23) S. BORKOWSKA, Strategie wynagrodzeń, Oficyna Ekonomiczna, Kraków 2001.

24) B.R. KUC, Od zarządzania do przywództwa, Wyd. Menedżerskie PTM, Warszawa 2004, s. 12.

25) B.R. KUC, Od zarzqdzania..., op.cit., s. 14.

26) W.E. FULMER, Human Resource Management: The Right Hand of Strategy Implementation, „Human Resource Planning", vol. 12, 1995, nr 4.

27) M. MAJCHERCZYK, Zarzadzanie wiedza zmienia role menedżera, „Manager” 2003, nr 3, M. HOLSTEIN-BECK, Jak być menedżerem, CIM, Warszawa 1996, s. 25.

28) A. GWIAZDA, Ewolucja menedżerskiej wiedzy, „Manager" 2002, nr 6.

29) B. WAWRZYNIAK, Budowanie przedsiębiorstwa opartego na wiedzy. O niektórych dylematach transformacji, [w:] (red.) A. LUDWICZYŃSKI, Najlepsze praktyki zarzadzania kapitatem ludzkim, Polska Fundacja Promocji Kadr, Warszawa 2002, s. 33.

30) W. RATYŃSKI, Menedżerskie $i$ organizatorskie metody zarzadzania, C.F. Müller. Akademia Prawa, Warszawa 2002 , s. 312 